\title{
DETERMINANTS OF ENTREPRENEURIAL ORIENTATION: A STUDY OF RURAL ENTREPRENEURS IN JIANGSU PROVINCE, CHINA
}

\author{
Michael Verner Menyah ${ }^{1 *}$ \\ ${ }^{1} \mathrm{PhD}$ Research Student, \\ School of Management, \\ Jiangsu University, \\ Jiangsu province 212013, \\ China PR;
Charles Dwumfour Osei ${ }^{3}$,
${ }^{3}$ PhD Research Student, School of Management, Jiangsu University, Jiangsu province 212013, China PR;

\author{
Jincai Zhaung ${ }^{2 *}$ \\ ${ }^{2}$ Professor, \\ School of Management, \\ Jiangsu University, \\ Jiangsu province 212013, \\ China PR;
}

\author{
Rejoice Akrashie ${ }^{4}$ \\ ${ }^{4} \mathrm{PhD}$ Research Student, \\ School of Management, \\ University of Professional Studies, \\ Ghana.
}

\author{
Enoch Darkwah ${ }^{5}$ \\ ${ }^{5}$ Master Research Student, \\ School of Management, \\ Jiangsu University, \\ Jiangsu province 212013, \\ China PR.
}

Article DOI: https://doi.org/10.36713/epra5408

\begin{abstract}
Small and Medium Enterprises (SMEs) in China have seen massive as well as viable progress in recent years owing to different factors which has progressively contributed to China's economic development. Frail bonds with external market and technological revolution, and limited SME funding, lack of proactiveness and risk taking is threatening the sustainability of such development and lowering the entrepreneurial orientation (EO) among the populace.

It is against this backdrop that this study was conducted to examine level of OE among Chinese firms as well as factors influencing the development of EO spirit among Chinese firms. The study used Statistical Package for Social Scientist (SPSS) and Microsoft Excel to conduct both descriptive and inferential analysis like mean, standard deviation, and graphical representation, t-test, Correlation, Multiple Regression Analysis, R-Square, F-statistics and Variance Inflator Factors (VIF) to determine the determinants of EO of four hundred (400) SMEs Jiangsu Province of China.

The finding of the study supported available literature and confirmed innovation, risk-taking and proactiveness to be the main determinants of entrepreneurial orientation. Other factors that affect $\mathrm{EO}$ included structural and relational support, availability of relevant resources, informalization of institutions as well as breaking down bureaucracies and extending corporate boundaries.
\end{abstract}

KEYWORDS: Entrepreneurial orientation, firms' performance, rural Jiangsu Province 


\section{INTRODUCTION}

Hamel (2000) asserts that firms operating in modern business environment must constantly position themselves well so as to subsist in the constantly mutable business environment. These among others will chiefly comprise capturing existing markets and at the same time crafting new markets, seizing market share from firms which are very conformist and less inventive and attain the customers, assets, and more drastically the employees of sluggish developing firms. But Ireland, Hitt and Sirmon (2003) observe that the degree to which a firm can accomplish these is highly contingent on its ability to demonstrate entrepreneurial leadership abilities. Current literature evidences that the entrepreneurial orientation of firms play a crucial role in this regard. Traditionally, entrepreneurial orientation has been hypothesized from three main scopes: innovativeness, proactiveness, and risk-taking (Miller, 1987). Innovativeness refers to the propensity for firms to espouse and upkeep creative processes, which may bring new products, new expertise, new services, new inventions, and new tests among others. Innovativeness propel enterprises to surge investment to roll out technology innovation activities such as new technology acquisition, new product development among others and thus can improve enterprise technological innovation ability (Lumpkin \& Dess, 1996; Wiklund, 1999). Proactiveness refers to the tendency for enterprises to take the positive marketing strategy, proactive action, and leading strategy to introduce new products, new processes, new technologies, and new services in order to transcend the competitors.

Risk-taking refers to the ability of firms to embark on bold actions and decisions which promote high rewards and it is seen on two levels which include technology as well as market. The technological dimension of risk-taking describes the disposition of enterprises to devote resources for technological invention approaches or ventures with a high risk of failure and vagueness and is meticulously linked to entrepreneurial risk penchants and attitudes towards new expertise. The essence of exploit can promote an enterprises' innovation, create new rules, and augment the competitive advantage of firms. The market dimension in contrast constitutes the eagerness and inclination of a firm to assume the uncertainty risk of entering a new market and is closely associated to the risk inclination of enterprises (Wiklund and Shepherd, 2003). Proceeding from this backdrop, this study shall seek to determine the factors which influence the entrepreneurial orientation of firms drawing on rural entrepreneurs in China.

\section{Preliminary Literature Review and Hypotheses Development}

Varied studies have been conducted on the determinants of entrepreneurial orientation and the impact of such on corporate performance (Zahra et al., 1999 and Bygrave, 1989). Scholars like Guth and Ginsberg(1990) and Morris et al., (1994) argued that enterprise associated factors tend to influence entrepreneurial orientation of firms. Other studies also concluded that some factors beyond the control of firms affects the orientations and for that matter are considered as external. The constructs to be used in the study proceed as follow:

\section{Enterprise Informalization}

As indicated by entrepreneurship researchers in literature, lesser amount of formalization flourishes new concepts (Stevenson and Gumpert, 1985; Covin and Slev, 1991; Zahra, 1993). "Enterprises were set-ups and processes are operated by non-flexible rules are less apparent to stimulate innovation as they are more inclined to realizing routines than goals" (Barringer and Bluedorn, 1999). Green et al. (2008) also mentioned that "Informal enterprises (organic structures) are those in which information are loosely and openly shared among the personnel, informal resist or contrivances and models of cooperation are used to shape individuals' behavior; lateral communication concentrates on consultation rather than command, the search of goals is often carried out with little anxiety for past practice or existing mechanism; and informal configurations of contact are used as the basis for altering and recurrently redefining processes and individual errands". Simply put, accomplishments are higher in more flexible enterprises.

Hypothesis (H1): Enterprise informalization has a positive stimulus on entrepreneurial orientation

\section{Compensation and Reward Schemes}

It is no deniable fact that recognizing and gratifying employees for performance stimulate them to remain loyal to the firm as well as and increasing their devotion to success and performance (Stevenson and Gumpert, 1985). Compensation schemes arouse the sense ownership in the employees and boost their loyalties and performance against competitors. According to Miller(1983) "value based compensation stimulate people to interconnect both internally and externally to better scan for prospects that increase firm value and thus making the whole firm more adaptive". This sense of ownership of enterprises increases capacity of employees to make change when indispensable in order to deal with different circumstances.

Hypothesis (H2): Compensation systems has a positive influence on entrepreneurial orientation 


\section{Resources Availability}

Access to funds permits entrepreneurs to belligerently exploit prospects well before time as compare to competitor who are forced to conform due to environmental compressions (Wernerfelt, 1984; Barney, 1986). Both physical and non-physical resources and assets are essential to device "valuecreating strategies" (Eisenhardt and Martin, 2000) as to take the advantage of opportunities by blossoming entrepreneurial orientation. Access to these vital means and their efficient allocation and scheduling is crucial to entrepreneurial orientation whiles the wastage and inefficient allocation of resources have dire consequences on entrepreneurship (Fahy, 2002).According to Timmons (1977) "operative entrepreneurial economic actions call for the business person to measure and clout resources to generate value addition". Entrepreneur should able to grasp prospect and then dedicate the necessary means in order to commendably perform entrepreneurial roles and exploit prospect. Honig and Davidsson (2000) and Baughn et al. (2006) exemplify access to resources using relational support which according to them can take the forms of emotional aids as well as the acquisition of finances from relatives

Hypothesis (H3): Access to Resources has a Positive Influence on Entrepreneurial Orientation

\section{Structural Support}

One other factor considered to impact EO positively is structural support. Most contemporary contexts of entrepreneurship are theorized using economic and political tools and are delimited by the individuals in the public, private and non-governmental sectors which cannot be discounted. Such systems therefore post either threats or prospects for entrepreneurs depending on how such structures are handled and managed. Barriers in the form of exacting rules against market entry have the tendency to hinder the capability for entrepreneurship. But if firms are given conditions acceptable and encouraging, individuals can take more risks (Gelard \& Saleh, 2011). Hypothesis (H4): Structural Support Positively Influence Entrepreneurial Orientation

\section{OBJECTIVES}

The study had the following objectives:

a. To determine the level of innovativeness, proactiveness and risk-taking habit among rural entrepreneurs in Jiangsu province.

b. To determine the factors that influences the entrepreneurial orientation of rural entrepreneurs in Jiangsu province.

\section{Research Questions}

Following the specified study objectives, the study answered the following questions:

What is the level of innovativeness, proactiveness and risk-taking habit among rural firms in Jiangsu province?

What factors influence the entrepreneurial orientation of rural entrepreneurs in Jiangsu province?

\section{LITERATURE REVIEW}

Studies have indicated that businesses' entrepreneurial orientation (EO) designates the degree to which they are entrepreneurially inclined, whether seen from the innovativeness, risk taking or proactiveness angle (Linton, 2016; Covin and Lumpkin, 2011; Saeed et al., 2014). In fact, entrepreneurial orientation underpin the very survival of firms today as it determine how rapid a firm expand by adopting new technologies, innovating new offerings and services and venturing into new arena of commerce by exploiting new markets. Miller set the ball rolling on the topic of entrepreneurial orientation in 1989 when he defined EO as "the attempt by firms to engage in product-market innovation, undertakes somewhat risky ventures, and coming up with proactive innovations with the aim of beating competitors to the punch". Rauch et al. (2009) also describe EO to mean an organization's ability to innovate, take risks, and proactively pursue market opportunities whiles Jinpei (2009) defined it as “an individual's attitude towards engaging in entrepreneurial activities, be it within an existing firm or creating a new venture". In their paper, Rauch et al., (2009) concluded that EO embodies the dogmas and practices that provide the foundation for entrepreneurial resolutions and initiatives and therefore influences entrepreneurs and small business owners in their engagement in business, product revolution and market advancement.

\section{Dimensions of EO and Performance}

As mentioned by Omisakin et al. 2016, The dynamic nature of ever changing business environment requires firms to recurrently innovate, take risks, give room for autonomy, be proactive, and aggressively compete if they are to improve performance whiles remaining competitive. Wang (2008) was also specific when he mentioned that $\mathrm{EO}$ is fundamental in business performance. The affiliation between the various dimensions EO and performance is drawn below:

\section{Innovativeness and Firms' Performance}

Covin and Slevin (1989) delineate innovativeness as the corporation's predisposition to engage in new idea generation, hypothesis testing, and research and expansion actions. It is a general consensus that without innovativeness, 
entrepreneurship cannot strive and that innovativeness is a fundamental part of firm subsistence strategies (Omisakin et al. 2016). Several researches have found a positive correlation stuck between innovation and firm performance (Rauch et al., 2009; Justine et al., 2005). The prominence of innovation as a backing variable to the assessment of EO and performance cannot be overemphasized (Omisakin et al. 2016).

\section{Proactiveness and Firms' Performance}

Proactiveness encompasses the revolutionmindedness, initiation inclination and advantageseeking struggles by firms to contour the market by introducing new offerings or processes prior of competition (Rauch et al. 2009; Lyon et al. 2000). Proactive corporations have higher outputs than their competitors since they react to market dynamisms immediately and are always ahead in the game (Hughes and Morgan 2007), thereby becoming frontrunners in their industry with prospects they unearth prior to their contenders (Lumpkinand Dess 1996). The claim above has been supported by several scholarly works on the correlation between EO and performance and advancement, most of which agreed to an affirmative liaison amid proactiveness and corporate performance both in the short and long run (Lumpkin and Dess 2001; Hughes and Morgan 2007; Rauch et al., 2009; Sascha et al., 2012).

\section{Risk Taking and Firms' Performance}

Risk-taking is the ability to master courage and invest in uncertain ventures, processes, procedure, technology, products or enter markets with uncertain returns or prospect. Lumpkin and Dess (2001) put it better by indicating that risk-taking entails investing in calculated business opening initiatives with limited determination of the viability of the said venture. Wiklund and Shepherd (2003) as their contribution to the subject opined that risk-taking is the willingness of a business entity to devote means in a ventures whose the outcome may be highly indeterminate and indefinite (Omisakin et al. 2016). Risk-taking may be in the form of borrowing heavily for business continuity, committing a huge chunk of funds to projects with inexact results or entering unknown business environments (Lyon et al. 2000). It is worth noting, however, that the bigger the risk, the bigger the returns and the other way round hence businesses who take calculated risks are likely to be ahead of others in terms of innovation, performance and growth.

\section{Determinant of Entrepreneurial Orientation (EO)}

The main determinants of entrepreneurial orientation $(\mathrm{OE})$ has be mentioned to be rooted to entrepreneurial intention which is either the impulsive or deliberate desire to constitute a novel business undertaking that is planned (Kureger et al., 2000). The Impulsive aspect of entrepreneurial intention has no convincing regulation on business resources and is mostly subjective to personal characteristics, culture or demographic features whiles the deliberate entrepreneurial intention is the inclination of an individual to undertake a commercial activity due to the viability of the business environment and infrastructural support. This aspect of entrepreneurial intension is dependent on external influencers such as preceding know-how or network-building or breakthrough in technology. That is to say that the individual managers and decision maker in firms are influenced by the above factors in deciding whether to invest a firm's resources into uncertain ventures or not.

Weerakoon, (2014), however, held an entirely different view as compared those expressed by many scholars. To him, the entrepreneurial orientation of firms is solely influence by factors domicile to the business which include dictates of top management, employee reward and compensation schemes, sagging and slack resources which activate entrepreneurship and entrepreneurial conduct of a corporation and construct varied impact in terms of inspiring entrepreneurship and entrepreneurial conduct of employees of corporations. Other schools of thoughts have it that EO is greatly shaped by environmental vagueness, lack of established structures and administrative interpretations of environmental doubts especially in developing countries (Hoskisson et al., 2000).

\section{Management Support and EO}

As mentioned by Hornsby et al., (1993), the inspiration and inclination of superiors to expedite entrepreneurial undertakings within a corporation is measured vital for stimulating entrepreneurial spirit within a corporation (Kuratko and Montagno, 1989). Such encouragement and willingness in the long run ensures viable competitive recompenses through novelty in the form of new offerings, services, and practices, or a mix of those (Quinn, 1985; Brentani, 2001; Hornsby et al., 2002).

\section{Autonomy and EO}

Autonomy refers to the dispensation given to employees to undertake their tasks self-reliantly with little or no supervision and such independence subject to no questions in cases of minimal deviation form operational standards in the chase of innovative activities (Hornsby et al., 2002) since autonomy and suppleness are indispensable influencers of an operative entrepreneurial climate of a company(Alpkan et al., 2010) 


\section{Rewards/Compensations and EO}

It is abundantly evident that rewards and compensations are prerequisite to aspiring a certain form of behaviour. The same is true in causing employees of an organisation to be entrepreneurially inclined. Extrinsic and intrinsic rewards are necessary to motivate employee and candle entrepreneurial spirit in a firm. That is to say employees who acknowledge that the reward system is honorable and constructs remunerations will be greatly influenced to obligate to innovative activities (Morrison and Robinson, 1997; Chandler et al., 2000) and will therefore undertake risk related activities related to entrepreneurial behaviour (Kuratko et al., 1990). These remunerations further galvanize innovative, proactive and modest risk-taking conduct of firms (Monsen et al., 2010).

\section{Structural Support and EO}

The precise provision of timely and financial resources and structural support for entrepreneurial activities within a corporation will permit the conception and development of practical entrepreneurial conduct and orientation (Pinchot, 1985; Covin and Slevin, 1991; Kreiser et al., 2002). Corporate procedures, systems and structures towards free time afford employees ample time to deliberate on new ideas, take risks and put their innovative ideas to test (Burgelman 1984; Fry, 1987; Sundbo, 1999; Hornsby et al., 2002). Satisfactory and timely provision and availability of resources and structural support will heighten a organization's capacity for carry out trial son new ideas proactively through research and development and innovation incubation avenues (Hornsby et al., 2002).

\section{Organizational Boundaries and EO}

Organizational boundary encompasses the administrative mechanism through which a firm conducts its business and the openness or closeness of such boundaries determines the entrepreneurial orientation of the firm as a whole. Thus, are assuring contrivance has to be put in place in to appraise, choose and outline successful ideas within organizations (Hornsby et al., 2002). An extremely inflexible organizational structure, for instance, restrict employees from recognizing ideas and prospects beyond their assigned duties and domain which in turn restrict the external attention of employees. Inversely, entrepreneurship within corporations thrives in an environment where the corporate structure is permitting and has a broader extent of restriction as well as creates openings for employees to act entrepreneurially (Ireland, 2006).

\section{CONCEPTUAL FRAMEWORK}

Generally, a conceptual framework is a portrayal of the inter-relatedness that exists between the variables in a scholarly work (Jabareen, 2009). In the diagram below, the construct between the dependent and the independent variables in this study is illustrated by a conceptual framework based on the literature review. The framework essentially illustrates that entrepreneurial orientation as operationalized measured by innovativeness, proactiveness and risks taking are influenced by the independent variables informationalisation, compensation systems, access to resources, and structural support. 


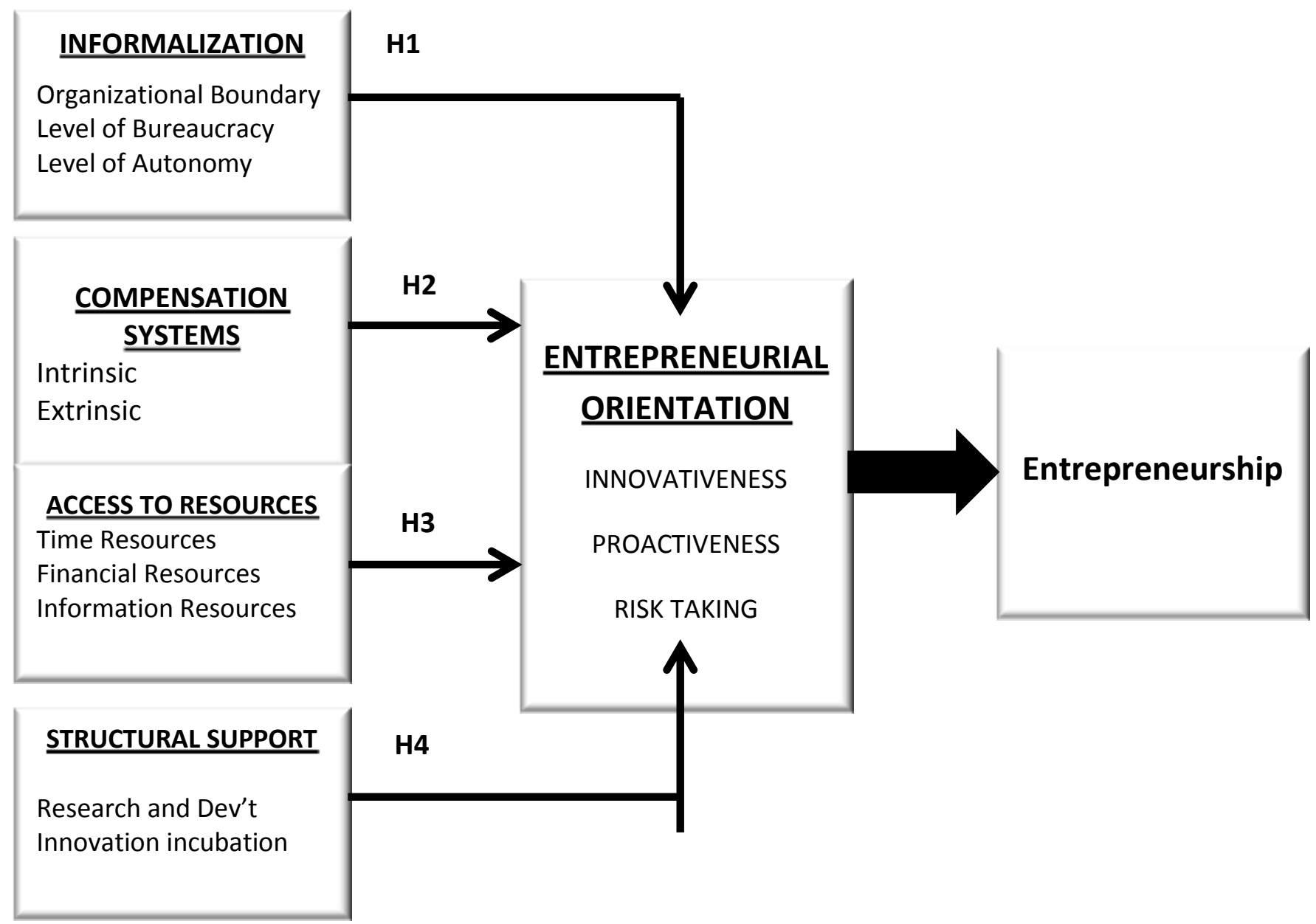

Figure 1: Conceptual framework

\section{METHODOLOGY}

This section of the study discourses the approaches employed by the researcher to attain the objectives set out. The section looks at the methodological fit of the study. Method is flair of steering a research work and is outlined by the nature of the problem. Keeping the nature of the problem in mind, the researcher carried out the present study on the lines of Descriptive Survey Method.

\section{population of the Study}

The population of the study was the Small and Medium Enterprises (SMEs) in the in Jiangsu province locality in the Jiangsu Province of China. The firms were drawn from agricultural, forestry and animal husbandry, mining, manufacturing, food processing, textile and leather works, metal industry, electrical, machinery and equipment, construction, transport, information technology (IT), hospitality, services and commerce industries.

\section{SAMPLE SIZE AND SAMPLING TECHNIQUE}

A sample of rural enterprises in the selected focal site was drawn from the population using simple random sampling in order to avoid biases in selection of respondents. Four hundred (400) firms were selected using convenience sampling method. To measure entrepreneurial orientation with reference to its constructs innovativeness, proactiveness, and risk taking, a 5-point Likert-scale was developed following the work of Covin and Slevin 1990 cited in Etriya et al., 2012). Questionnaire was used as the research instrument of data collection. Validity and reliability was achieved using face validity test and Cronbach alpha test respectively. Innovativeness operationally measured with the questions related to $\mathrm{R} \& \mathrm{D}$, new products, and radical changes; proactiveness with questions related to initiative, pioneer, and 
competitiveness; risk taking with questions related to high-risk project, obtaining objectives, and exploring new opportunity. Descriptive statistics comprising mean scores and standard deviations and inferential statistical techniques comprising regression will be used.

\section{Variables of the Study}

Two main variables-dependent and independent variable were considered in this study

\section{Independent Variables}

In the present study, organizational boundary, level of bureaucracy, level of autonomy, intrinsic and extrinsic reward and compensation, availability of time, financial and information resources, research and development avenues and innovation incubation programs serve as independent variables of the study.

\section{Dependent Variables}

Entrepreneurial Orientation is considered as dependent variable in the study.

\section{Method of Data Analysis}

The study was descriptive in nature, explaining the relationship between variables. Statistical Package for Social Scientist (SPSS) and Microsoft Excel were used to conduct both descriptive and inferential analysis. The descriptive statistics include mean, standard deviation, and graphical representation while the inferential analysis included t-test, Correlation, Multiple Regression Analysis, R-Square, F-statistics and Variance Inflator Factors (VIF).

\section{DATA PRESENTATION AND ANALYSIS}

This section of the study analyzes and accord empirical connotations to the data gathered by the study. It gives a systematic description of data on the major determinants of the study which is entrepreneurial orientation, made a factor analyses that lead to the development of correlations of the main concepts and test the hypothesis set out by the researcher.

\section{Level of Entrepreneurial Orientation in China}

The first objective of the study was to determine the level of entrepreneurial orientation in China by assessing the level of innovation, proactiveness, and risk taking habit. Table 4.1 shows the data gathered:

Table 5.1 Level of Entrepreneurial Orientation

\begin{tabular}{lrrrc}
\hline & MIN & MAX & MEAN & Standard Deviation \\
\hline New Product utilization & 1 & 5 & 3.60 & 0.958 \\
Adopting new technology & 1 & 4 & 3.73 & 0.777 \\
Acquiring new services & 1 & 5 & 3.73 & 0.003 \\
Producing new inventions & 2 & 5 & 3.33 & 0.698 \\
Adopting and supporting creative processes & 2 & 5 & 3.46 & 0.654 \\
Rewarding innovativeness & 1 & 5 & 3.82 & 0.886 \\
Innovation Incubation programs & 1 & 5 & 3.60 & 1.120 \\
Investing in future uncertain projects & 1 & 5 & 3.73 & 0.958 \\
Entering new markets & 1 & 5 & 3.85 & 0.003 \\
\hline
\end{tabular}

Source: Fieldwork, 2020

From the table it was seen the least mean score recorded was 3.33 from a mean score of 1 and a maximum score of 5, an indication that the level of level of entrepreneurial orientation is extremely high as seen from all indicators used by the researcher. Figure
4.1 also show another dimension of measuring the level of entrepreneurial orientation. 
Figure 5.1 Other Determinant of Entrepreneurial Orientation

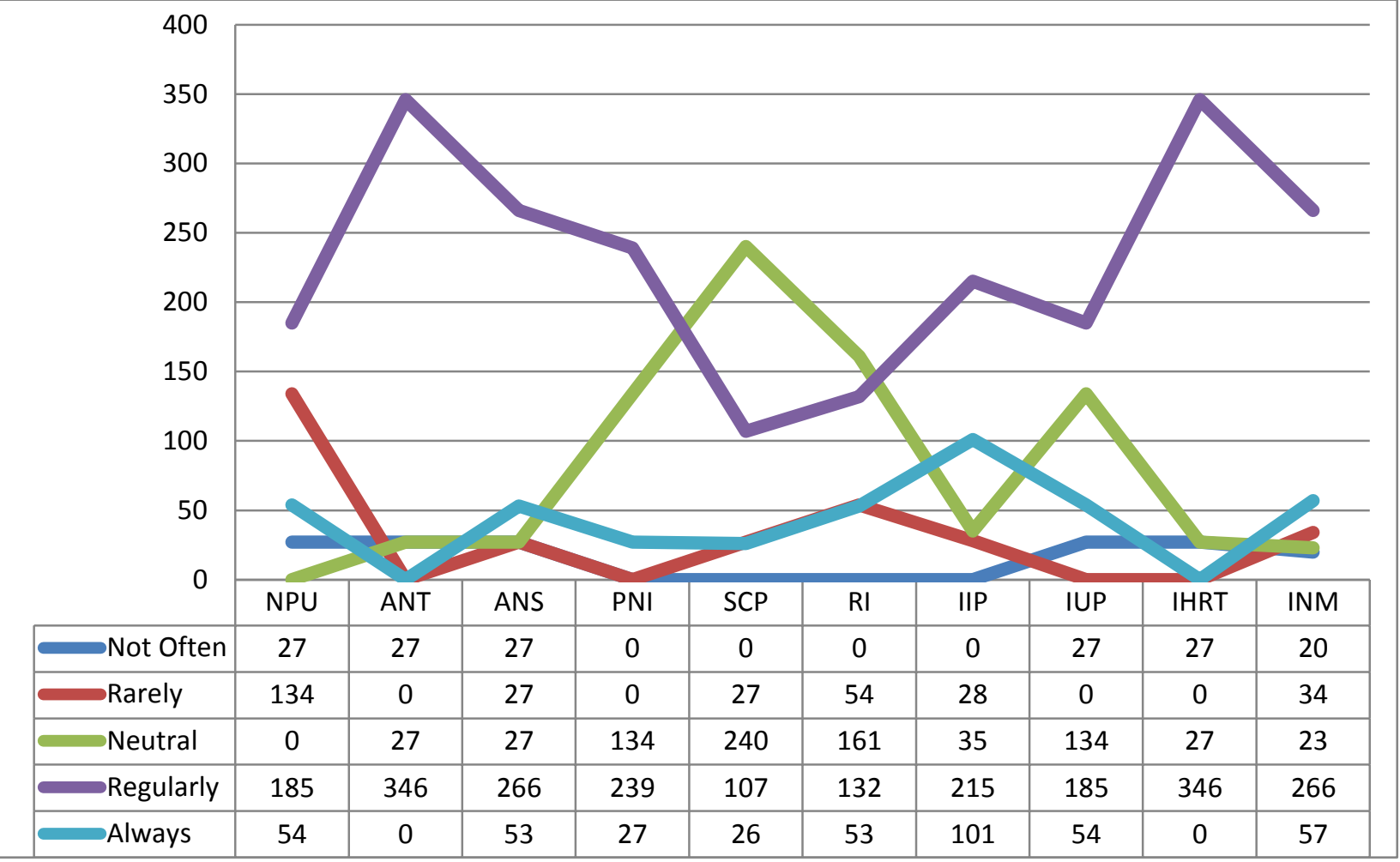

NPU- New Product Utilization, ANT-Adopting New Technology, ANS-Acquiring New Services

PNI-Producing New Inventions, SCP-Supporting Creative Processes, RI-Rewarding Innovativeness, IIPInnovation Incubation Programs, IUP-Investing in Uncertain Projects, IHRT-Investing Innovation with High Risk, INM-Entering New Markets

Source: Fieldwork, 2020

The Levene test below further entrenched the claims identified below:

Table 5.2 Levene Test Result

\begin{tabular}{|c|c|c|c|c|c|}
\hline \multirow{2}{*}{ Dimension } & \multicolumn{2}{|c|}{ Mean } & t-value & Significance & Std. Error \\
\cline { 2 - 6 } & FI & DE & & & \\
\hline Innovativeness & 5.000 & 4.652 & 1.959 & 0.049 & 0.178 \\
Risk-Taking & 4.379 & 4.146 & 1.418 & 0.158 & 0.164 \\
Proactiveness & 5.428 & 4.956 & 2.483 & 0.014 & 0.190 \\
EO & 4.935 & 4.584 & 2.793 & 0.006 & 0.126 \\
\hline
\end{tabular}

Source: Fieldwork, 2020

Based on the results, p-value was greater than 0.05 in all cases except for that of proactiveness $(\mathrm{p}=0.01)$. Thus, unequal variances were assumed for proactiveness and equal variances for all the other models.

The first hypothesis addresses the levels of innovativeness by China firms and it could be seen that the level of innovativeness is very high (5.000 with a pvalue of 0.049).

Rotated factor loading the various dimensions of entrepreneurial orientation is shown below: 
Table 5.3: Rotated Factor Loading of the Dimensions of EO

\begin{tabular}{|c|c|c|c|c|c|c|c|c|}
\hline \multirow{3}{*}{ Item } & \multicolumn{8}{|c|}{ Component } \\
\hline & \multicolumn{2}{|c|}{1} & \multicolumn{2}{|c|}{2} & \multicolumn{2}{|c|}{3} & \multicolumn{2}{|c|}{4} \\
\hline & $\mathrm{Fl}$ & DE & $\mathrm{Fl}$ & $\mathrm{DE}$ & $\mathrm{FI}$ & $\mathrm{DE}$ & $\mathrm{FI}$ & DE \\
\hline Innovativeness 1 &, 702 & & & & & & &, 693 \\
\hline Innovativeness 2 & ,794 & & & & & & &, 842 \\
\hline Innovativeness 3 & ,964 &, 638 & & & & & & \\
\hline Innovativeness 4 &, 789 &, 775 & & & & & & \\
\hline Innovativeness 5 &, 663 &, 774 & & & & & & \\
\hline Risk-taking 1 & & &, 686 &, 637 & & & & \\
\hline Risk-taking 2 & & & &, 599 & 640 & & & \\
\hline Risk-taking 3 & & &, 900 &, 691 & & & & \\
\hline Risk-taking 4 & & &, 784 &, 707 & & & & \\
\hline Proactiveness 1 & & & & &, 805 & ,906 & & \\
\hline Proactiveness 2 & &, 673 & & & & & ,708 & \\
\hline Proactiveness 3 & & & & &, 779 & ,903 & & \\
\hline Proactiveness 5 & &, 600 & & & & &, 730 & \\
\hline
\end{tabular}

Source: Fieldwork, 2020

Based on the Kaiser criterion of eigen values greater than one as suggested by Field (2009), the three-dimensions of EO was established with factor loadings vacillating from 0.652 to 0.918 . Together these factors accounted for $78.4 \%$ of the variance. Overall, the pattern of factor loadings is steady in both settings. The Cronbach's alphas measuring reliability were also above the satisfactory level of 0.7 defined by Nunnally (1978) with 0.776 .

\section{Determinants of Entrepreneurial Orientation}

This section of the study assessed the determinants of entrepreneurial orientation in China using various dimensions like structural support, relational support, firms' informalization among others.

\section{Reliability and Validity of Variables}

Reliability is often used to measure internal steadiness of the exploration construct. A scale is said to have high internal consistency reliability if the items of a scale measure similar construct (Robinson, 2009). The reliability and internal consistency of the study's instrument was assessed using Cronbach alpha. Generally, Cronbach's alpha should exceed the acceptable value of 70 (Hair et al., 2014).

The results indicates that the alpha coefficients were .816 for differentiation, .782 for cost leadership, .761 for focus strategy, .801 for organizational culture and .894 for firm performance. From the table, it can be seen that the Cronbach's alpha of the study constructs all exceeded the minimum .70 threshold which makes 
the construct suitable for further studies (Hair et al., 2014). The study also estimates the goodness of fit parameters of the overall model.

The most commonly used parameters for this assessment are Chi-square ( $\mathrm{X} 2)$, Degree of Freedom (df), Root Mean Square Error of Approximation (RMSEA), Non Normed Fit Index (NNFI), Comparative Fit Index (CFI), Standardized Root Mean Residual (SRMR). The result were, $\mathrm{x} 2=324.16$, df $=124, X^{2} / \mathrm{df}=2.61$, the RMSEA was 0.46 , NNFI was
0.94, CFI was 0.96 , and SRMR was 0.33 . The study found that the measurement model results showed a very good model fit, making the data therefore suitable for further analysis.

Regression Analysis

The regression analysis is conducted based on the conceptual model of the study. In the model, there are four hypotheses. The fitness of the models was examined using R-Square, F-statistics and Variance Inflator Factors (VIF).

Table 5.4 Regression Analysis Matrix

\begin{tabular}{|c|c|c|c|c|c|}
\hline & $\begin{array}{l}\text { Firm } \\
\text { Performance }\end{array}$ & $\begin{array}{l}\text { Firm } \\
\text { Performance }\end{array}$ & $\begin{array}{l}\text { Firm } \\
\text { Performance }\end{array}$ & & \\
\hline Variables & Beta(t-value) & Beta (t-value) & Beta (t-value) & Beta (t-value) & Result \\
\hline $\begin{array}{l}\text { Enterprise } \\
\text { informalization }\end{array}$ & $.151(2.324)$ & & & & Supported \\
\hline $\begin{array}{l}\text { Compensation } \\
\text { systems }\end{array}$ & & $.217(4.847)$ & & & Supported \\
\hline $\begin{array}{l}\text { Access to resources } \\
\text { Structural support }\end{array}$ & & & .614 (10.347) & .331 (5.463) & $\begin{array}{l}\text { Supported } \\
\text { Supported }\end{array}$ \\
\hline \multicolumn{6}{|l|}{ Model Indices } \\
\hline R Square & .213 & .271 & .412 & .334 & \\
\hline F statistics & 25.837 & 36.487 & 45.247 & 41.364 & \\
\hline Sig. & .003 & .000 & .000 & .001 & \\
\hline
\end{tabular}

Note: ${ }^{*} \mathrm{p}<.05$; hypothesized paths are evaluated at $\mathrm{t}>/=1.645$ (5\% sig. level), $\mathrm{t}$-values are in parenthesis.

Field Study 2020

\section{Hypothesis Testing}

Based on the regression analysis shown in table 4.2, the hypotheses set out are tested below:

\section{The Effect of Enterprise In formalization} on Entrepreneurial Orientation

Firstly, the study analyzed the effect of Enterprise informalization on entrepreneurial orientation. From the table, the result of the regression analysis accentuated that Enterprise informalization has a positive and statistically significant effect on the entrepreneurial orientation $(\beta=.151, \mathrm{t}=2.324$, $\mathrm{p}$ <0.05). Thus, the hypothesis 1, that there's a significant positive relationship Enterprise informalization, and entrepreneurial orientation is accepted. The implication is that Enterprise informalization improves entrepreneurial orientation. Furthermore, the table indicated that, Enterprise informalization explains up to $21.3 \%$ variability in the entrepreneurial orientation.

The finding of the examination has been certified by existing writings. Business specialists (Stevenson and Gumpert, 1985; Covin and Slevin, 1991; Zahra, 1993) ponder that a lower level of formalization invigorates groundbreaking thoughts. Enterprises where activities and strategies are worked by recommended rules are less conceivable to empower advancement, since "they are more arranged towards accomplishing measures than objectives" (Barringer and Bluedorn, 1999). As per Green et al. (2008), "informal associations (natural structures) are those in which data are broadly and transparently gave among the representatives, casual control components and the standard of participation are utilized to coordinate people's activities; parallel correspondence centers interview as opposed to order, the hunt of objectives is frequently completed with little worry for past training or existing systems; lastly casual examples of connection are utilized as the reason for altering and ceaselessly rethinking cycles and individual duties". In short exercises are more adaptable in big business.

The Effect of Compensation Systems on Entrepreneurial Orientation

The study also analyzed the effect of Compensation systems on entrepreneurial orientation. From the result of the regression analysis indicated, Compensation systems recorded positive coefficients 
values with entrepreneurial orientation $(\beta=.217, \mathrm{t}=$ 4.847, $\mathrm{p}<0.05)$. Thus, Compensation system has a positive relationship with entrepreneurial orientation. Therefore, if the index of Compensation systems increases, entrepreneurial orientation will mostly likely to increase as well. Furthermore, Compensation system has $27.1 \%$ relative change on entrepreneurial orientation. Therefore, the hypothesis 2, that there's a significant positive relationship between Compensation systems and entrepreneurial orientation is supported.

This finding of the study is line with existing literatures. Recognizing staff for performance inspire them to stay intact with businesses for extended amount of your time and upsurges their allegiances still as devotions (Stevenson and Gumpert, 1985).Employees contemplate the construct of owning the enterprise and enhance their loyalties against their contender. in line with Miller(1983) "value primarily based compensation guides folks to speak each internally and outwardly to raised scan for opportunities that increase enterprise worth, creating the total enterprise a lot of adaptive". This act of owner or businessperson will increase ability of their staff to create amendment once necessary so as to agitate completely different things.

\section{The Effect of Access to Resource on Entrepreneurial Orientation}

The study also analyzed the effect of access to resource on entrepreneurial orientation. From the result of the regression analysis, access to resource recorded positive coefficients values with entrepreneurial orientation $(\beta=.614, \mathrm{t}=10.347, \mathrm{p}<0.05)$. This implies that access to resource is positively associated with entrepreneurial orientation. Therefore, arise in access to resource will result to an increase in entrepreneurial orientation. Access to resource explains $41.2 \%$ of variability in entrepreneurial orientation. Therefore, the hypothesis 3, that there's a significant positive relationship between access to resource and entrepreneurial orientation is supported.

This finding of the study has confirmed existing literatures. Access to resources allows the bourgeois to sharply exploit opportunities well before time as compare to competition rather than because of environmental pressures (Wernerfelt, 1984; Barney, 1986). Resources like physical and intangible assets are components necessary to implement "value-creating strategies" (Eisenhardt and Martin, 2000) and to use opportunities by flourishing entrepreneurial orientation. Access to resources so its economical reallocation or reorganizing is important to entrepreneurial orientation, otherwise wastage of accessible resources is adverse or offset to entrepreneurship (Fahy, 2002).According to Timmons (1977) "effective entrepreneurial economic activity needs the business person to access and leverage resources to form worth addition". Bourgeois ought to be ready to grab chances so as to commit the required resources and effectively perform entrepreneurial role and exploit the chance. Honig and Davidsson (2000) and Baughn et al. (2006) exemplify access to resources exploitation relative support that per them will take the kinds of emotional support and/or the acquisition of funding from friends and family.

\section{The Effect of Structural Support on Entrepreneurial Orientation}

The study also evaluated the effect of Structural support on entrepreneurial orientation. From the table, the result of the regression analysis revealed that Structural support has a positive and statistically significant effect on the entrepreneurial orientation $(\beta=$ $.331, \mathrm{t}=5.463, \mathrm{p}<0.05)$. The implication is that Structural support ameliorates entrepreneurial orientation. Furthermore, the table indicated that, Structural support explains up to $33.4 \%$ variability in the entrepreneurial orientation. Thus, the hypothesis 4, that there's a significant positive relationship Structural support, and entrepreneurial orientation is supported.

This finding of the study has academic backing. The actual fact that the present context of entrepreneurship is wrought by economic and political tools that are regulated by the people within the public, personal and non-governmental sectors can't be discounted. Such a system will impose threats or opportunities for entrepreneurs. For instance, barriers that take the shape of harsh laws to entry into a market could lower the capability for entrepreneurship. However if companies are given conditions acceptable and inspiring, people will take a lot of risks (Gelard \& Saleh, 2011).

\section{Summary of Findings and Conclusion}

This final section of this paper abridges the findings of this study and laid the theoretical contribution of the thesis and provides insinuations of the study based on the outcomes obtained.

\section{RESULTS MAIN FINDINGS}

The finding of this study was targeted on the amount of entrepreneurial orientation (EO) in China additionally because the determinants of EO among China corporations. It absolutely was examined that management support, rewards and time and resource accessibility encourage completely affects EO behavior of corporations. Hypotheses testing confirmed that the higher the management support, rewards and time and resource accessibility are, the higher the chance of EO inclination by staff. Management ought to create make a conscious effort and demonstrate high level of commitment to encouraging staff to engage in 
innovative practices by providing applicable rewards and making accessible the specified time and resources needed. Sturdy support for brand spanking, new idea generation and experimentations and acceptance of worker suggestions, championing projects with staff and tolerance for failures in innovation development are essential for higher EO level. Higher recognition with extrinsic and intrinsic rewards for entrepreneurial activities of staff would be of tremendous significance in this perspective as instructed by the findings of Sheepers et al. (2008), Antoncic \& Hisrich (2001); Hornsby et al. (2002) and Morris \& Kuratko, (2002)

The study also revealed that Chinese firms are highly inclined in terms of entrepreneurial orientation as they score high across all the indicators used. They for instance are proactive, takes risk and innovative, accounting for the rapid growth in the small and medium enterprises (SMEs) in China

\section{CONCLUSION}

Because performance and entrepreneurial orientation are strongly inter-twined positively affects each other, managers and policy maker needs to pay attention to the various dimensions of EOproactiveness, risk-taking, innovativeness and autonomy. For firms to stay ahead of competition and remain in business, it is extensively suggested for small and medium enterprises to engage entrepreneurial orientation in their corporate dealings.

Another area that needs to be looked at is the paradigm shift in the educational curricular to be more entrepreneurially oriented as education and prior expertise in entrepreneurial ventures were seen to impact entrepreneurial orientation absolutely and momentously. Individual with extraordinary level of schooling and expertise are more prospective to participate in entrepreneurial activities. An individual with further work familiarity, higher level of education, more knowledge of the market and corporate expertise is more likely to be able to recognize an opportunity for commencing business (Wit and VanWinden, 1989).

The need for independence and encouraging self-achievement can also not be overemphasize as they have a positive and significantly correlation with the entrepreneurial orientation.

\section{REFERENCES}

1. Alpkan, L., Bulut, C., Gunday, G., Ulusoy, G., \&Kilic, K. (2010). Organizational support for Intrapreneurship and its interaction with human capital to enhance innovative performance. Management Decision, 48(5), 732-755.

2. Antoncic, B., \& R.D. Hisrich. (2001). Intrapreneurship: Construct refinement and cross- cultural validation.Journal of Business Venturing. 16(5), 495-527,

3. Brentani, U. (2001). Innovative versus incremental new business services: Different keys for achieving success, The Journal of Product Innovation Management: 181-187.

4. Burgelman, R.A. (1984). Managing the internal corporate venturing process, Sloan Management Review, 25(2): 33-48.

5. capability. Southern African Business Review, 12(3), 50-75

6. Chandler, G., \& Lyon, D. (2001). Issues of Research Design and Construct Measurement in Entrepreneurship Research: The Past Decade, Entrepreneurship Theory and Practice, 101-116.

7. Chandler, G.N., Keller, C., \& Lyon, D.W. (2000). Unravelling the determinants and consequences of an innovation-supportive organizational culture. Entrepreneurship Theory and Practice, 25(1): 5976.

8. Covin, J. G. and D. P. Slevin (1990). "New venture strategic posture, structure, and performance: An industry life cycle analysis." Journal of Business Venturing 5(2): 123-135.

9. Covin, J. G., \&Slevin, D. P. (1991). A conceptual model of entrepreneurship as firm behavior. Entrepreneurship: Theory and Practice. 16(1), 724, Available at:

10. Covin, J.G. and Wales W.J., 2011. The Measurement of Entrepreneurial Orientation. Entrepreneurship Theory and Practice, [e-journal] Published online. Available through: Wiley Online Library [Accessed 2 November 2011].

11. Covin, J.G., \&Slevin, D.P. (1988). The Influence of Organization Structure on the Utility of an Entrepreneurial Top Management Style. Journal of Management Studies. 25(3), 217-259.

12. Cromie, S. (2000). Assessing Entrepreneurial Inclination: Some approaches and empirical evidences. European Journal of Work and Organizational Psychology, 1, 7-30.

13. Dess, G.G. and Lumpkin, G.T., 2005. The role of entrepreneurial orientation in stimulating effective corporate entrepreneurship. Academy of Management Executive, 19(1), pp. 147-156.

14. Eisenhardt KM, Martin JA (2000). Dynamic capabilities: What are they? Strategic Management Journal.21:1105-1121.

15. Etriya, E., Wubben, E. F. M., Scholten, V. E., \& Omta, S. W. F. (2012). Exploring factors related to entrepreneurial orientation and innovation capacity of farms. A lesson from vegetable farmers in West Java.

16. Fry, A.S. (1987). The post it Note: An entrepreneurial success, SAM Advanced Management Journal, 52(3):4-9.

17. Hamel, G. (2000). Leading the revolution. Boston, MA: Harvard Business School Press

18. Hornsby, J.S., Kuratko, D.F., \& Zahra, S.A. (2002). Middle managers' perception of the internal 
environment for corporate entrepreneurship: Assessing a measurement scale, Journal of Business Venturing, 17: 253-273.

19. Hornsby, J.S., Naffziger, D.W., Kuratko, D.F., \&, Montagno, R.V. (1993). An interactive model of the corporate entrepreneurship process, Entrepreneurship Theory and Practice, 24(2): 9-24.

20. Hoskisson, R.E., Eden, L., Lau, C.M. \& Wright, M. (2002), "Strategy in emerging economies", AIreland, R.D., Covin, J.G. \&Kuratko, D.F. (2009), "Conceptualizing corporate entrepreneurship strategy”, Entrepreneurship Theory \& Practice, 33(1), 19-46.cademy of Management Journal, 43(3), 249-67.

21. http://kisi.deu.edu.tr//ethem.duygulu/covin\%20ve\% 20slevin.pdf

22. Hughes, M. and Morgan, R. E., 2007. Deconstructing the relationship between entrepreneurial orientation and business performance at the embryonic stage of firm growth. Industrial Marketing Management, 36(5), pp. 651661.

23. Ireland, R.D. M.A. Hitt and D.G. Sirmon. 2003. A model of strategic entrepreneurship: The construct and its dimensions. Journal of Management 29(6): 963-990.

24. Jinpei W. (2009). Entrepreneurial orientation, entrepreneurial intent and new venture creation: Test of a framework in a Chinese context, PHD dissertation, Blacksburg, Virginia. http://hdl.handle.net/10919/28298.

25. Justine, A., Anthony, L., \& Max, C. (2005). The impact of entrepreneurial orientation on the Australian automotive component industry. Working paper 17/05, Department of management, Monash

University. http://pandora.nla.gov.au/pan/44459/200701230000/wp17-05.pdf

26. Kreiser, P. M., Marino, L. D. and Weaver, K. M., 2002. Assessing the psychometric properties of the entrepreneurial orientation scale: A multi-country analysis. Entrepreneurship Theory and Practice, 26(4), pp. 71-92.

27. Kuratko, D.F., \& Montagno, R.V. (1989). The entrepreneurial spirit, Training and Development Journal, 43(10): 83-87.

28. Lumpkin G.T. \&Dess G.G. (1996). Clarifying the entrepreneurial orientation construct and linking it to performance. The Academy of Management Review. 21(1), 135-172,

29. Lumpkin, G. T., \& Dess, G. G. (1996). Clarifying the entrepreneurial orientation construct and linking it to performance. Academy of management Review, 21(1), 135-172.

30. Lumpkin, G.T., \&Dess, G.G. (2001). Linking two dimensions of entrepreneurial orientation to firm performance: The moderating role of environment and industry life cycle. Journal of Business Venturing.16 (16), 429-451
31. Lyon, D. W., Lumpkin, G. T., \& Dess, G. G. (2000). Enhancing entrepreneurial orientation research: Operationalizing and measuring a key strategic decision making process. Journal of Management, 26(5), 1055-1085.

32. Miller, D. (1983). The Correlates of Entrepreneurship in Three Types of Firms. Management science, 770-791

33. Monsen, E., H. Patzelt\& T. Saxton (2010), Beyond Simple Utility: Incentive Design and Trade-offs for Corporate Employee-Entrepreneurs, Entrepreneurship Theory \& Practice, 105-130.

34. Morrison, E.W., \& Robinson, S.L. (1997). When employees feel betrayed: A model of how psychological contract violation develops, Academy of Management Review, 22(1): 226-25.

35. Pinchot, G. (1985). Intrapreneuring, New York, NYHarper and Row.

36. Quinn, J.B., (1985). Managing innovation: controlled chaos, Harvard Business Review, 63: 73-84.

37. Rauch, A., Wiklund, J., Lumpkin, G. T. and Frese, M., 2009. EntrepreneurialOrientation and Business Performance: An Assessment of Past Research and Suggestions for the Future. Entrepreneurship Theory and Practice, 33(3), pp. 761-787.

38. Sascha, K. J. P., Coen, R., Marthew, H., \& Vincent, $H$. (2012). Entrepreneurial orientation and business performance of SMEs: A quantitative study from the Netherlands. Review of management science, 6(2), 161-182.

39. Scheepers, M. J., Hough, J., \& Bloom, J. Z. (2008). Nurturing the corporate entrepreneurship

40. Sundbo, J. (1999). Empowerment of employees in small and medium-sized service firms, Employee Relations, 21(2): 105-127.

41. Timmons J.A. (1977). New venture creation, 3rd edition. Homewood, IL: Irwin

42. Weerakoon, C. (2014) Organizational Determinants of Entrepreneurial Orientation: (With Reference to Small Scale ITBPO Firms in Sri Lanka): International Journal of Science and Research (IJSR).

43. Wiklund, J. (1999). The sustainability of the entrepreneurial orientation-performance relationship. Entrepreneurship theory and practice, 24(1), 37-48.

44. Wiklund, J. and Shepherd, D. (2005). Entrepreneurial Orientation and Small Business Performance: A configurational Approach. Journal Business Venturing, 20 (1): 71-91.

45. Wiklund, J., \& Shepherd, D. (2005). Entrepreneurial orientation and small business performance: A configurational approach. Journal of Business Venturing. 20, 71-91.

46. Wit, G. and VanWinden, F., 1989. An empirical analysis of self-employment in the Netherlands. Small Business Economics; 1(4), 263-272 